\title{
Kandungan Pigmen Fikobiliprotein dan Biomassa Mikroalga Chlorella vulgaris pada media dengan Salinitas Berbeda
}

\author{
Ali Djunaedi*, Sunaryo, Chrisna Adi Suryono dan Adi Santosa \\ Departemen IImu Kelautan, Fakultas Perikanan dan IImu Kelautan, Universitas Diponegoro \\ JI. Prof. Soedarto, SH. Kampus UNDIP Tembalang, Semarang 50275 \\ Email : alidjunaedi@ymail.com
}

\begin{abstract}
Phyobilliprotein (phycocyanin and allophycocyanin) pigments content and biomass of Chlorella vulgarisare affected by salinity related to osmotic pressure and density of media. This study was to determine the effect of salinity on phycobiliproteins pigment contents and biomass of microalgae Chlorella vulgaris. The cultivation used microalgae derived from Balai Besar Pengembangan Budidaya Air Payau (BBPBAP), Jepara. Research method was the Laboratory study with a Completely Randomized Design (CRD). Consisting of one treatment with five stages of salinity treatments: 20, 25, 30, 35, and 40 ppt and using three times of repetition. Analysis of pigments used UV-Vis spectrophotometric extracted with acetone as the solvent. Harvesting time was when it reached at the stationair phase using flocculation method. The results showed that salinity had the significant effect $(p<0.05)$ on Phycobilliprotein pigment and biomass. The treatments of 35 ppt showed that the highest content of phycocyanin and allophycocyanin pigments 1,4426 mg/gram and 1,254 mg/gram and biomass were $0,648 \mathrm{~g} / \mathrm{L}$ respectively.
\end{abstract}

Keywords: Chlorella vulgaris, salinity, Phycobilliprotein pigment, biomass.

\begin{abstract}
Abstrak
Kandungan pigmen fikobiliprotein (fikosianin dan allofikosianin)dan biomasa Chlorella vulgaris dipengaruhi oleh salinitas yang berkaitan dengan tekanan osmotik dan densitas media. Tujuan dari penelitian ini adalah untuk mengetahui pengaruh salinitas terhadap kandungan pigmen fikobiliproteindan laju pertumbuhan Chlorella vulgaris. Biota uji diperoleh dari Balai Besar Pengembangan Budidaya Air Payau (BBPBAP), Jepara. Metode penelitian adalah eksperimen laboratoris dengan Rancangan Acak Lengkap (RAL) yang terdiri dari 5 taraf perlakuan salinitas, yaitu: 20, 25, 30, 35, dan 40 ppt dengan pengulangan sebanyak 3 kali. Analisis pigmen dengan metode spektrofotometer UV-Vis yang diekstraksi menggunakan larutan aseton. Pemanenan biomassa pada fase stasioner dengan menggunakan metode flokulasi. Hasil penelitian menunjukkan bahwa salinitas berpengaruh nyata $(p<0.05)$ terhadap kandungan pigmen fikobiliprotein dan biomasa Chlorella vulgaris. Perlakuan salinitas $35 \mathrm{ppt}$ menghasilkan kadar pigmen fikosianin dan allofikosianin tertinggi, yaitu 1,4426 mg/gram, dan $1,254 \mathrm{mg} / \mathrm{gram}$ dan biomassa tertinggi yaitu $0,648 \mathrm{gr} / \mathrm{L}$.
\end{abstract}

Kata Kunci : Chlorella vulgaris, salinitas, pigmen fikobiliprotein, biomasa

\section{PENDAHULUAN}

Sampai saat ini mikroalga masih menjadi komoditas kelautan yang potensial untuk dikembangkan.Hal ini dikarenakan mikroalga merupakan sumberdaya alami yang mempunyai manfaat yang sangat luas sebagai sumber asam lemak, asam amino, dan pigmen baik untuk hewan maupun manusia. Mikroalga juga masih digunakan oleh masyarakat sebagai bahan pangan fungsional yang mempunyai keunggulan di aspek keamanannya bila dibandingkan 
dengan sumber lain seperti yeast maupun fungi (Azimatun, 2014). Beberapa mikroalga bahkan digunakan sebagai sumber obat obatan,dan dimanfaatkan dalam industri farmasi.

Chlorella vulgaris adalah salah satu jenis mikroalga yang mengandung khlorophyl dan pigmen lainnya untuk melakukan fotosintesis. Mikroalga ini dapat tumbuh pada kisaran salinitas yang cukup lebar, dan bahkan Chlorella vulgaris dapat tumbuh disemua tempat (kosmopolit), kecuali pada tempat yang ekstrim. Mikroalga dapat melakukan biosintesa bahan kimia bernilai tinggi seperti protein, asam lemak tidak jenuh berantai panjang (LC-PUFA) dan pigmen. Akan tetapi, pertumbuhan mikroalga dan komposisi biokimia yang terbentuk sangat dipengaruhi oleh cara budaya dan kondisi lingkungan budidayanya (Rodriguezet al., 2015). Hal tersebut mengakibatkan pemanfaatan mikroalga bervariasi tergantung dari komposisi bahan yang terkandung.Beberapa pigmen yang umum digunakan dalam industry adalah klorofil, fikobiliprotein dan karotenoid.

Beberapa penyebab utama yang mempengaruhi terhadap proses psikokimia akibat dari kondisi stress pada pembentukan asam lemak dan pigmen adalah salinitas, intensitas cahya dan temperature. Salinitas adalah faktor eksternal yang dapat menjadi pemicu utama stress dan penghambat pertumbuhan pada biota air. Salinitas yang ekstrim akan menyebabkan tekanan osmotik dan atau pertukaran ion yang berpengaruh terhadap metabolisme organisme fotosintetik. Sejumlah penelitian telah menemukan efek salinitas terhadap bioenergetik mikroalga (Loseva et al., 2007) dan pertumbuhan dan komposisi biokimia (Gu Na et al., 2012).

Pigmen adalah zat kimia berwarnawarniyang merupakan bagian dari sistem fotosintesis pada mikroalga. Pigmen dibedakan menjadi tiga kelas: karotenoid, klorofil, dan fikobiliproteins(Barra et al., 2014).Fikobiliproteins merupakan pigmen aksesori dalam alga merah dan cyanobacteria dan merupakanbahan berharga tinggi. Beberapa fikobiliproteins umum termasuk phycocyanin (PC), allophycocyanin (APC) dan phycoerythrin (PE). Phycobiliproteins telah digunakan pewarna alami yang non-toksik dan nonkarsinogenik; Selain itu, pigmen ini juga secara luas telah digunakan sebagai nutraceuticals atau aplikasi lainnya pada bidang bioteknologi (Manirafasha et al., 2016). Penelitian ini bertujuan untuk mengetahui kandungan pigmen fikobiliproteins (fikosianin dan allofikosianin) pada Chlorella vulgaris pada konsisi media dengan salinitas yang berbeda.

\section{MATERI DAN METODE}

Penelitian dilakukan pada bulan Nopember 2015 - Januari 2016. Materi yang digunakan adalah mikroalga jenis Chlorella vulgaris yang diperoleh dari Balai Besar Pengembangan Budidaya Air Payau (BBPBAP), Jepara. Kultur mikroalga jenis Chlorella vulgaris menggunakan media walne yang dimodifikasi dengan salinitas, $20,25,30,35$ dan 40 ppt dan dilaksanakan di Laboratorium Pakan Alami dan analisis pigmen di Laboratorium Kimia,Balai Besar Pengembangan Budidaya Air Payau (BBPBAP), Jepara.

Analisis pigmen polar Chlorella vulgaris menggunakan pelarut buffer fosfat $\mathrm{pH} 7$ (NaOH-KH $\left.\mathrm{PO}_{4}\right)$. Chlorella vulgaris kering seberat 0,6 gram dihaluskan dengan menggunakan mortar dan setelah halus tambahkan pelarut sebanyak $10 \mathrm{~mL}$. Kemudian sampel dimasukkan ke tabung sentrifuse untuk diinkubasi selama 14 - 16 jam dalam refrigenerator. Selanjutnya adalah filtrat yang diperoleh disentrifugasi dengan menggunakan spektrofotometer pada kisaran panjang gelombang $562 \mathrm{~nm}$, $620 \mathrm{~nm}$, dan $652 \mathrm{~nm}$ (Sedjati et al., 2012).

\section{HASIL DAN PEMBAHASAN}

\section{Kandungan PigmenChlorella vulgaris}

Hasil penelitian menunjukkan bahwa kandungan pigmen fikosianin pada $C$. vulgaris dengan salinitas berbeda, secara berurutan adalah perlakuan D (35 ppt) $1,4426 \pm 0,0306 \mathrm{mg} / \mathrm{gr}$, perlakuan $C$ (30 ppt) $0,4491 \pm 0,0211 \mathrm{mg} / \mathrm{gr}$, perlakuan B (25 ppt) $0,6462 \pm 0,0402 \mathrm{mg} / \mathrm{gr}$, perlakuan E (40 ppt) $0,8614 \pm 0,0187 \mathrm{mg} / \mathrm{gr}$, dan $\mathrm{A}$ (20 ppt) $0,0164 \pm 0,0018 \mathrm{mg} / \mathrm{gr}$. 
Kandungan pigmen allo-fikosianin seara berurutan adalah E (40 ppt) dengan $1,2537 \pm 0,0283 \mathrm{mg} / \mathrm{gr}$, perlakuan $\mathrm{D}$ (35 ppt) $0,5986 \pm 0,0119 \mathrm{mg} / \mathrm{gr}$, B (25 ppt) 0,5652 \pm $0,0487 \mathrm{mg} / \mathrm{gr}, C(30 \mathrm{ppt}) 0,2935 \pm 0,0357$ $\mathrm{mg} / \mathrm{gr}$, dan perlakuan A (20 ppt) 0,0389 \pm $0,0045 \mathrm{mg} / \mathrm{gr}$.

Hasil penelitian menunjukkan bahwa salinitas berbeda berpengaruh nyata $(p<0,05)$ terhadap kandungan pigmen klorofil fikosianin dan allofikosianin mikroalga Hasil uji menunjukkan bahwa perlakuan salinitas berpengaruh nyata $(p<0,05)$ terhadap kandungan pigmen klorofil fikosianin dan allofikosianin mikroalga Chlorella vulgaris. Hal tersebut diduga karena salinitas berpengaruh terhadap tekanan osmotik yang mempengaruhi pembentukan pigmen. Menurut Golldack et al. (1995) menyatakan bahwa stressing salinitas baik dibawah maupun diatas salinitas normal akan mengakibatkan menurunkan sintesa pigmen pada mikroalga.

Kadar pigmen fikobiliprotein (fikosianin dan allofikosianin) yang tinggi (Gambar1) terjadi pada perlakuan dengan salinitas yang relatif tinggi (35 ppt). Hal ini diduga dikarenakan pada pada salinitas yang tinggi akan mengakibatkan menurunnya intensitas cahaya yang masuk pada media pemeliharaan tidak optimal, sehingga akan mengakibatkan turunnya kandungan pigmen fikobiliprotein pada salinitas diatas dan dibawah 35 ppt. Menurut Mata et al. (2010) bahwa perubahan salinitas mempengaruhi mkroalga dengan tiga cara yaitu tekanan osmotik, tekanan ion dan perubahan rasio ionik akibat permeabilitas membrane. Pada salinitas tinggi sel mikroalga mampu bertahan hidup karena adanya bantuan gliserol yang berfungsi sebagai mendukung tekanan osmotik untuk menyeimbangkan proses osmolaritas pada sel bagian luar (extracellular). Salinitas yang tinggi menyebabkan berkurangnya cairan yang ada pada sel sehingga akan mempengaruhi proses fotosintesis (Avron, 1992). Menurut Manirafashaet al. (2016) kebanyakan microalgae mengakumulasi dari pigmen fikobiliprotein pada saat terjadinya stressing faktor lingkungan medianya. Produksi pigmen fikobiliprotein akan semakin tinggi bila intensitas cahaya yang masuk optimal.

\section{Biomassa Chlorella vulgaris}

Hasil panen biomassa kering tertinggi didapat pada perlakuan D (35 ppt) sebesar 0,648 $\pm 0,007 \mathrm{gr} / \mathrm{L}$, diikuti perlakuan E (40 ppt) sebesar 0,630 $\pm 0,007 \mathrm{gr} / \mathrm{L}$, diikuti perlakuan $C$ (30 ppt) sebesar 0,624 $\pm 0,004$ $\mathrm{gr} / \mathrm{L}$, dan perlakuan B (25 ppt) sebesar 0,620 $\pm 0,003 \mathrm{gr} / \mathrm{L}$. Produksi biomassa kering terendah didapat pada perlakuan A (20 ppt) sebesar 0,619 $\pm 0,002 \mathrm{gr} / \mathrm{L}$ (Gambar 2) .

Hasil penelitian menunjukkan bahwa salinitas berbeda berpengaruh nyata $(p<0,05)$ terhadap pembentukan biomasa mikroalga Chlorella vulgaris (Gambar 2). Hal tersebut diduga perbedaan salinitas

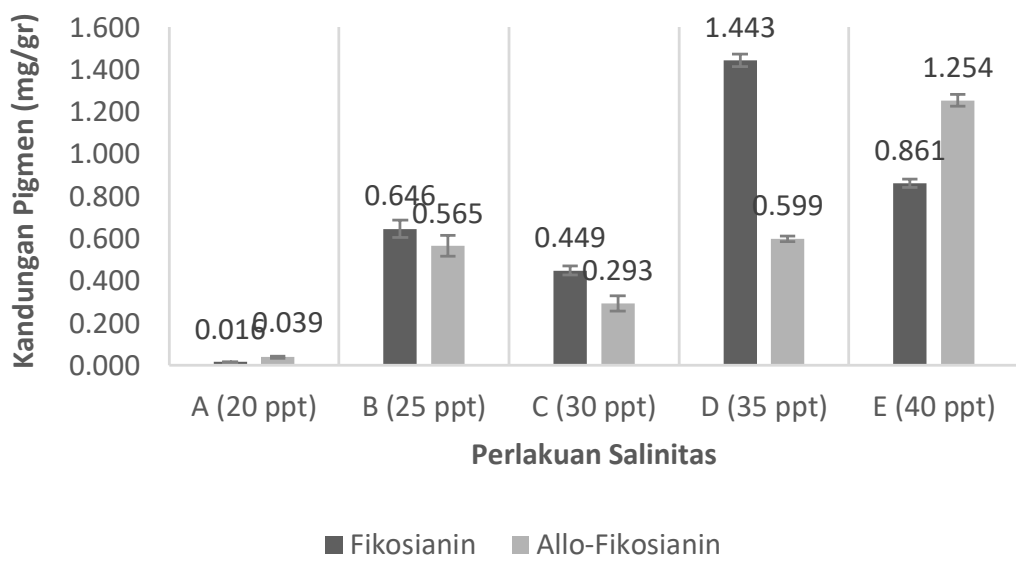

Gambar 1. Kandungan Pigmen Fikosianin dan Allo-Fikosianin pada salinitas berbeda 


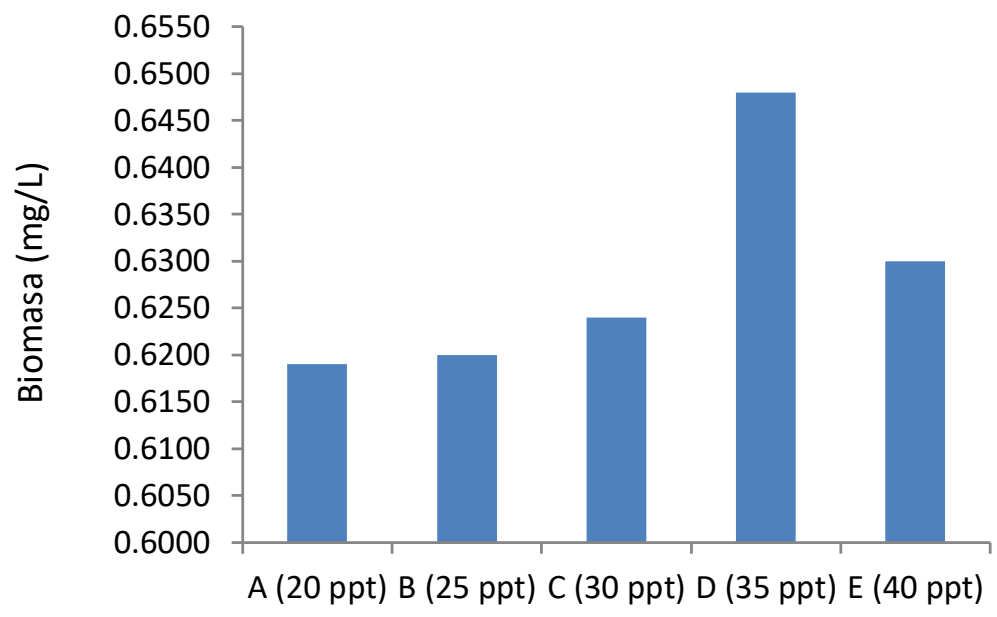

Gambar 2.Kandungan Biomasa Chlorella vulgaris pada salinitas berbeda.

berpengaruh terhadap tekanan osmotik pada media tumbuh, sehingga akan mempengaruhi proses metabolisme serta pembentukan biomasa pada sel Chlorella vulgaris. Menurut Adenan (2013) bahwa salinitas memiliki peran pada kelangsungan hidup mikroalga dan dapat menyebabkan penghambatan aktivitas metabolisme akibat menurunnya fotosintesis yang berkaitan dengan pembentukan biomassa.

Hasil uji menunjukkan bahwa biomasa teringgi (Gambar 2) terjadi pada perlakuan dengan salinitas 35 ppt. Hal tersebut diduga pada salinitas $35 \mathrm{ppt}$ merupakan salinitas yang optimal untuk pertumbuhan dan pembentuk biomassa Chlorella vulgaris. Menurut Merizawati (2008) bahwa Chlorella vulgaris dapat tumbuh optimal pada salinitas 10-35 ppt, microalga akan tetap bereproduksi secara asexual dengan pembelahan sel dan pemisahan autospora dari sel induknya. Sedangkan menurut shen et al. (2015) menyatakan bahwa laju pertumbuhan dan pembentukan biomasa Chlorella vulgaris akan turun pada media dengan salinitas rendah, hal tersebut berhubungandengan menurunnya efisiensi fotosintesis akibat stress disebabkan oleh salinitas.

\section{KESIMPULAN}

Salinitas berpengaruh nyata terhadap kadar pigmen fikoboliprotein (fikosianin dan allofikosianin) pada mikroalga Chlorella vulgaris. Kadar pigmen fikoboliprotein dan biomassa tertinggi dicapai pada salinitas 35 ppt.

\section{DAFTAR PUSTAKA}

Adenan, N.S., Yusoff,F. Md.\& Shariff, M. 2013. Effect of Salinity and Temperature on the Growth of Diatoms and Green Algae. J. Fish. Aqua. Sci. 8(2):397-404.

Avron, M. 1992. Osmoregularity, in Dunaliella: Physiology, Biochemistry and Biotechnology, edited by $M$. Avron dan A Ben Amotz. CRC Press, Boca Raton, Florida, 135-164.

Azimatun,N.M.M. 2014. Potensi Mikroalga sebagai Sumber Pangan Fungsional di Indonesia (Overview). Eksergi.11 (2):0106.

Barra, L., Chandrasekaran, R., Corato, F. \&Brunet, C., 2014. The challenge of ecophysiological biodiversity for biotechnological applications of marine microalgae. Mar. Drugs 12:1641e1675.

Gu, N., Lin, Q., Li,G., Tan, Y., Huang,L.\& Lin, J. 2012. Effect of Salinity on Growth, Biochemical Composition and Lipid Productivity of Nannochloropsis oculata CS 179. Eng. Life Sci. 12(5):1-7.

Golldack, D; Dietz, K.J.\& Gimmleri, H. 1995.The Effects of Sudden Salt Stress on Protein Synthesis in the Green Alga Dunaliella parva. J. Plant Physiol. 146: 508-514.

Loseva, N.L., Alyabyev, A. J., Gordon, L.K., Andreyeva, I.N., Kolesnikov, O.P., 
Ponomareva, A.A., \& Kemp, R.B. 2007. The effect of AgNO 3 on the bioenergetic processes and the ultrastructure of Chlorella and Dunaliella cells exposed to different saline conditions. Thermochimica acta, 458(1):71-76.

Manirafasha, E.A., Ndikubwimanaa, T., Zengb X., Lua, Y. \&Jing, K. 2016. Phycobiliprotein: Potential microalgae derived pharmaceutical and biological reagent. Biochemical Engineering Journal 109:282-296.

Mata, T.M., Martins, A.A., \& Caetano, N.S., 2010. Microalgae for biodiesel production and othe application: A review. Renewable andSustainable Energy Reviews, 14:217-232.

Merizawati. 2008. Analisis sinar merah, hijau dan biru untuk mengukur kelimpahan fitoplankton Chlorella vulgaris. Institut Pertanian Bogor. 87 hal.

Shen, Q. H., Gong, Y. P., Fang, W. Z., Bi, Z. C., Cheng, L. H., XU, X. H., \& Chen, H. L. 2015. Saline wastewater treatment by Chlorella vulgaris with simultaneous algal lipid accumulation triggered by nitrate deficiency. Bioresource Technology. 193:68-75.

Rodríguez, J.C., Cerón-García, M.C., Fernández-Sevilla, J.M., \& MolinaGrima, E. 2015. The influence of culture conditions on biomass and high value product generation by Nannochloropsis gaditana in aquaculture. Algal Research, 11:63-73. Sedjati, S., Yudiati, E., \& Suryono. 2012. Profil Pigmen Polar dan Non Polar Mikroalga Laut Spirulina sp. dan Potensinya sebagai Pewarna Alami. IImu Kelautan. 17(3):176-181. 